\title{
Representasi Matrik Brightness Pola Gaussian Dengan Proyeksi Paralel Kaidah Tangan Kanan
}

\author{
Destriana Widyaningrum \\ Program Studi Teknik Informatika \\ Universitas Bunda Mulia \\ Jakarta, Indonesia \\ des3ana@gmail.com
}

\author{
Teady Matius Surya Mulyana \\ Program Studi Teknik Informatika \\ Universitas Bunda Mulia \\ Jakarta, Indonesia \\ tmulyana@bundamulia.ac.id
}

\begin{abstract}
Image evenly brightening evenly using Gaussian patterns requires visualization of its appearance so that matrix users can have information on how the Gaussian brightness matrix can do image brightness alignment. Three-dimensional graphs are graphs that have $X, Y$ and $Z$ coordinates. Gaussian brightness matrix visualization to dimensional charts requires the implementation of three-dimensional coordinates $\mathrm{X}, \mathrm{Y}$ and $Z$ which will represent the matrix cell address and matrix cell values. The visualization process of the Gaussian brightness matrix to a three-dimensional graph will be carried out by the rules of the right hand. In this research, the implementation of the matrix cell address into $X$ and $Y$ coordinates and the value of each cell will be implemented into $Z$ coordinates. The use of the right hand rule in parallel projection facilitates implementation because this process only needs to be placed in accordance with the nature of the cells in sequence so voxels stacked in the direction of the Observer according to the order of their depth.
\end{abstract}

Keywords- 3D; Brightness; Gaussian; Matrix; Parallel; Projection.

\begin{abstract}
Abstrak - Pencerahan gambar secara merata menggunakan pola Gaussian memerlukan visualisasi penampilannya sehingga pengguna matriks dapat mempunyai informasi bagaimana matriks Gaussian brightness dapat melakukan perataan kecerahan citra. Grafik tiga dimensi merupakan grafik yang memiliki koordinat $\mathrm{X}$, Y dan $\mathrm{Z}$. Visualisasi matriks Gaussian brightness ke grafik dimensi memerlukan implementasi koordinat tiga dimensi $\mathrm{X}, \mathrm{Y}$ dan $\mathrm{Z}$ yang akan merepresentasikan alamat sel matriks dan nilai sel matriks. Proses visualisasi matriks Gaussian brightness ke grafik tiga dimensi akan dilakukan dengan kaidah tangan kanan. Pada penelitian ini dirancang implementasi dari alamat sel matriks menjadi koordinat $\mathrm{X}$ dan $\mathrm{Y}$ serta nilai dari masingmasing sel akan diimplementasikan menjadi koordinat $Z$. Penggunaan kaidah tangan kanan pada proyeksi parallel memudahkan implementasi karena proses ini hanya perlu menempatkan sesuai dengan alamat sel nya secara berurutan sehingga voxel bertumpuk urut kearah Pengamat sesuai dengan urutan kedalamannya.
\end{abstract}

Keywords-3D; Brightness; Gaussian; Matriks; Paralel, Proyeksi.

\section{PENDAHULUAN}

Beberapa pra-proses pada visi komputer memerlukan penyebaran pencahayaan yang baik,[1][2][3] tetapi tidak semua pengambilan gambar pada komputer vision memiliki penyebaran cahaya yang baik. Sistem pencahayaan buatan yang sering dipergunakan secara umum atas 3 macam yakni
Sistem pencahayaan merata, Sistem pencahayaan terarah dan Sistem pencahayaan setempat.[4] Pencahayaan mempengaruhi nilai intensitas pixel, dimana penampilan dari background dan foreground dipengaruhi oleh intensitas piksel.[5]

Sifat dari penyebaran cahaya menyerupai distribusi normal, hal ini yang mendasari proses perataan cahaya berdasarkan pola matriks Gaussian brightness.[6] Matriks Gaussian brightness pada penelitian perataan kecerahan citra dengan menggunakan pola Gaussian memerlukan visualisasi penampilannya sehingga pengguna matriks dapat mempunyai informasi bagaimana matriks Gaussian brightness dapat melakukan perataan kecerahan citra. Pada pemakaiannya, pengguna matriks Gaussian brightness sukar untuk menebak seperti apa bentuk matriks yang akan dipergunakan dan apakah sesuai dengan kasus citra yang akan diproses perataan kecerahannya..

Proyeksi paralel pada grafik 3 dimensi merupakan adalah sekumpulan titik-titik 3D yang dipengaruhi oleh sudut-sudut terhadap bidang proyeksi dan terhadap. Penerapan kaidah atau metode tangan kanan pada proyeksi parallel mensyaratkan sumbu x yang bernilai positif mengarah ke kanan, sumbu y yang bernilai postif mengarah ke atas, sedangkan sumbu $\mathrm{z}$ yang mengarah ke pengguna adalah sumbu ke arah positif.

Penelitian ini diperlukan untuk menghasilkan informasi secara visual bentuk-bentuk dari matriks Gaussian brightness. Visualisasi ini diperlukan agar pengguna matriks Gaussian brightness dapat memperkirakan model perataan kecerahan citranya berdasarkan visualisasi secara graphis dari matriks Gaussian brightness yang diperoleh dari input citra. Visualisasi pada penelitian terdahulu hanya menggambarkan penyebaran intensitas dalam grafik 2D seperti yang diperagakan pada Gambar 6. Visualisasi ini memang memberikan informasi nilai intensitas tetapi tidak dapat memberikan informasi kecuraman kurtosis secara visual yang lebih mudah dicerna. Objektif dari penelitian ini adalah membuktikan bahwa proyeksi paralel dengan kaidah tangan kanan sesuai dengan kadar kedalaman dari kurva 3D matriks Gaussian brightness sehingga penyusunan voxel pembentuk kurva tersebut tidak memerlukan usaha yang besar.

\section{A. Proyeksi 3D Paralel Dengan Kaidah Tangan Kanan.}

Grafik 3 dimensi adalah sekumpulan titik-titik 3D yang membentuk bidang muka - bidang muka yang digabungkan menjadi satu. Proyeksi merupakan perubahan dari tampilan dua dimensi menjadi multi tampilan sehingga memberikan 
kesan gambar 3D.[7] Titik P(x,y,z) yang diperagakan pada gambar 1 dinyatakan dalam bentuk 3D terdiri dari koordinat $\mathrm{X}$, y dan z. Titik $\mathrm{P}$ merupakan titik dari bidang 3D yang terdapat pada posisi $\mathrm{x}$ pada sumbu $\mathrm{X}$, koordinat y pada sumbu $\mathrm{Y}$ dan koordinat $\mathrm{z}$ pada sumbu $\mathrm{Z}$. Penyajian titik $\mathrm{P}(\mathrm{x}$, $\mathrm{y}, \mathrm{z})$ merupakan penyajian titik pada suatu bidang $3 \mathrm{D}$ pada bidang 2D. Layar komputer disajikan dalam struktur 2D. Sehingga diperlukan konversi dari 3D menjadi 2D.

Proyeksi parallel sendiri merupakan suatu penyajian 3D pada bidang $2 \mathrm{D}$ dengan prinsip tiap garis dan titik disajikan secara parallel. Proyeksi parallel meskipun bukan merupakan kondisi ideal dari suatu realita secara visual, tetapi dapat memberi gambaran perbandingan ukuran pada grafik. Proyeksi paralel merupakan proyeksi 3D dengan asumsi semua rusuk diproyeksikan dalam proporsi yang sama tanpa mempertimbangkan adanya perspektif pada sudut pandang pengamat.[7] Tujuan dari proyeksi paralel adalah untuk menggambarkan objek sesuai dengan proporsi nya sehingga mempermudah pengamatan dan membayangkan proporsi ukuran.[8]

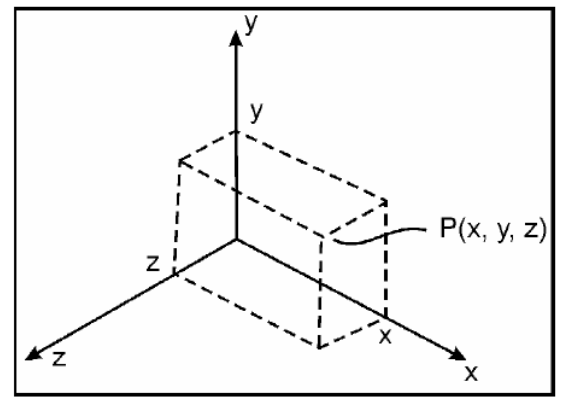

Gambar 1. Koordinat 3D

Jika Xp dan Yp adalah koordinat pada proyeksi seperti yang diperagakan pada Gambar 2. Garis proyeksi dari (x,y,z) ke (xp,yp) membentuk sudut $\alpha$ dengan garis pada bidang proyeksi dan $\Phi$ adalah sudut yang terbentuk dari garis proyeksi dengan arah horisontal pada bidang proyeksi, dan garis proyeksi dinyatakan dengan $\mathrm{L}$. Titik $\mathrm{P}(\mathrm{x}, \mathrm{y}, \mathrm{z})$ pada obyek 3D diproyeksikan ke titik $\mathrm{P}(\mathrm{Xp}, \mathrm{Yp})$ pada bidang $2 \mathrm{D}$.

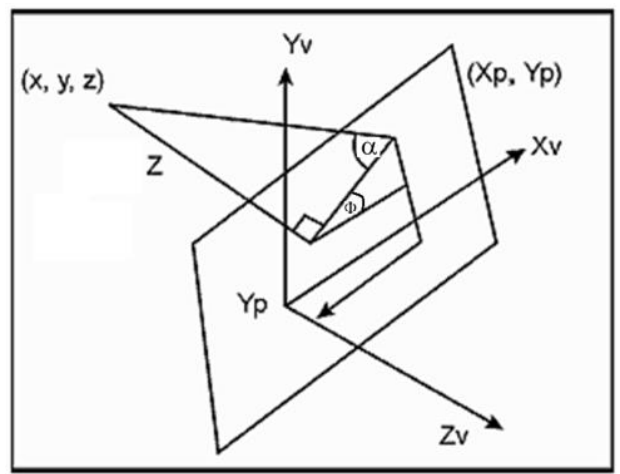

Gambar 2. Proyeksi Paralel

Koordinat Proyeksi Paralel Xp dan Yp dapat dihitung dengan rumus (1) dan rumus (2). Koordinat Xp didapat dari koordinat X. Koordinat Z berkontribusi sebagai penambah atau pengurang nilai $\mathrm{X}$ menjadi $\mathrm{Xp}$. $\mathrm{Z}$ berkontribusi dengan perbandingan terhadap tangen sudut $\alpha$ dan cosinus dari sudut $\Phi$ sebagai penguat nilai.[9]

Hal yang sama juga pada koordinat proyeksi paralel Yp. Koordinat $\mathrm{Z}$ berkontribusi sebagai penambah atau pengurang nilai Y menjadi Yp. Z berkontribusi dengan perbandingan terhadap tangen sudut $\alpha$ dan sinus dari sudut $\Phi$ sebagai penguat nilai. [9]

$$
\begin{aligned}
& X p=X+Z \frac{1}{\tan \alpha} \cos \Phi \\
& Y p=Y+Z \frac{1}{\tan \alpha} \sin \Phi
\end{aligned}
$$

Penyajian proyeksi parallel memerlukan asumsi arah sumbu Z yang negatif dan positif. Pada penelitian ini dipergunakan kaidah tangan kanan untuk mengasumsikan arah sumbu Z. Ilustrasi kaidah tangan kanan diperagakan pada Gambar 3.

Kaidah tangan kanan merupakan sistem koordinat yang berlawanan arah jarum jam.[10][11] Kaidah tangan kanan menyajikan arah sumbu X yang ditunjukkan oleh arah ibu jari ke arah kanan, sebagai sumbu x positif, jadi yang ke arah kiri merupakan sumbu $\mathrm{x}$ negative. Sedangkan untuk arah sumbu Y ditunjukkan oleh telunjuk ke arah atas sebagai arah sumbu positif. Untuk sumbu $\mathrm{Z}$ diperagakan oleh jari tengah yang ke arah positif. Jari tengah menunjuk ke arah pengamat, dengan demikian kaidah tangan kanan menyajikan sumbu $\mathrm{Z}$ ke arah pengamat adalah sumbu $Z$ positif, sedangkan sumbu $\mathrm{Z}$ yang menjauhi pengamat adalah sumbu $\mathrm{Z}$ negatif.[12][13]

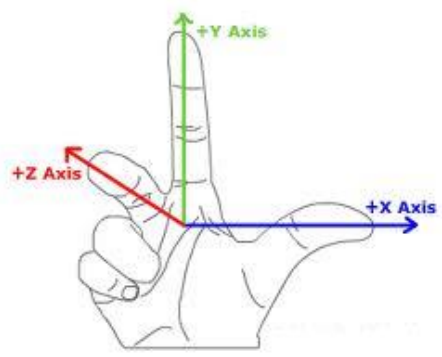

Gambar 3. Kaidah Tangan Kanan Koordinat 3D

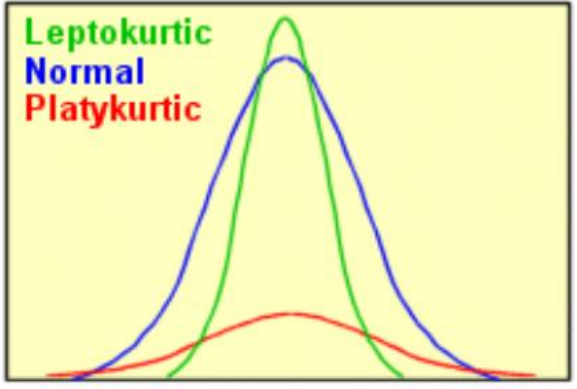

Gambar 4. Kurtosis

\section{B. Kurtosis}

Ada tiga jenis kurtosis yang ditunjukkan pada Gambar 4. Zero kurtosis atau distribusi Gaussian disebut sebagai Mesokurtic, yang disebabkan oleh nilai standar deviasi sama dengan jarak sel terjauh dari pusat matriks.[14] Kurtosis positif yang disebut Leptokurtic, disebabkan sementara nilai 
standar deviasi kurang dari jarak sel terjauh dari pusat matriks. Kurtosis negatif disebut sebagai Platykurtic disebabkan nilai standar deviasi lebih besar dari jarak sel terjauh dari pusat matriks.[14] [15]

Nilai deviasi standar yang lebih besar membuat kurva lebih fokus, dan semakin kecil nilai standar deviasi membuat kurva lebih rata.[16]

\section{Matriks Gaussian Brightness}

Pada penelitian terdahulu oleh Mulyana, telah dirancang proses pemerataan kecerahan citra menggunakan pola Gaussian.[6] Seperti yang ditunjukkan pada gambar 5. Gambar tersebut menunjukkan citra yang memiliki perbedaan kecerahan akibat pencahayaan yang tidak merata ketika citra diambil.

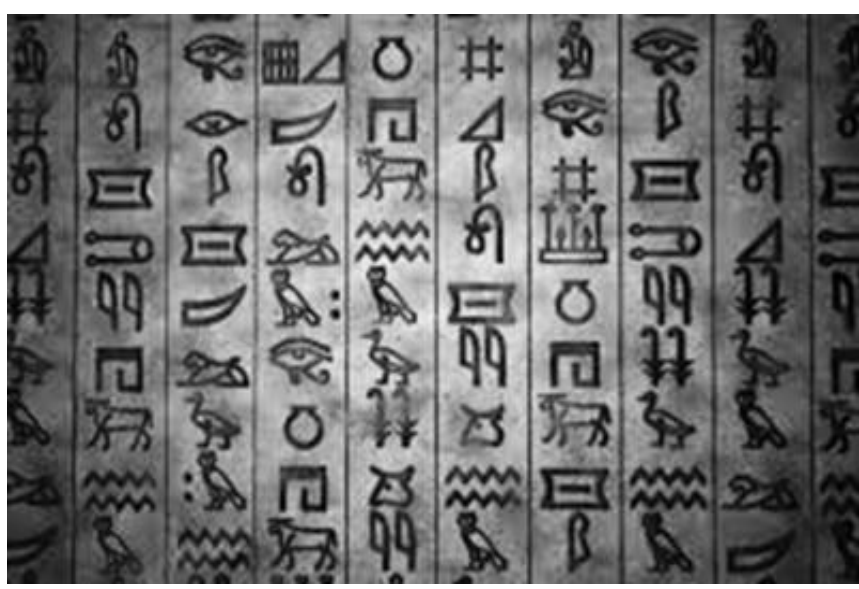

Gambar 5. Citra Dengan Cahaya yang tidak merata

Sedangkan matriks pola gaussian yang dihasilkan ditunjukkan pada gambar 6. Pada gambar tersebut terlihat bagian tengah yang gelap dikarenakan nilai pola matriks mempunyai nilai pengurang intensitas yang tinggi pada bagian yang gelap tersebut, yang menandakan proses pengurangan nilai intensitas yang rendah. Matriks tersebut semakin mengecil ke bagian pinggir yang menandakan nilai pengurang yang semakin kecil.

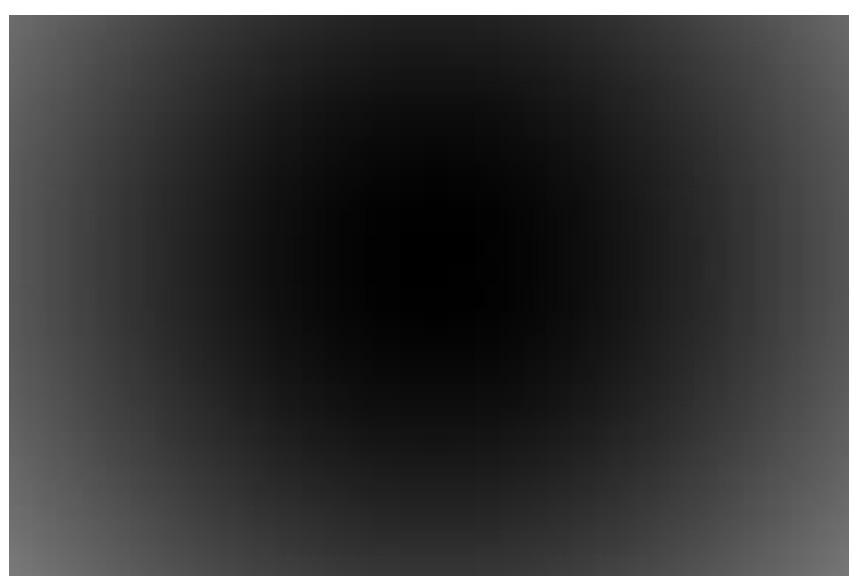

Gambar 6. Visualisasi Matriks Gaussian

Hasil dari perataan kecerahan citra menggunakan matriks Gaussian brightness diperagakan pada gambar 7. Pada gambar tersebut diperlihatkan bagian pinggi dari citra yang semula gelap dan kontras terhadap bagian tengah seperti pada gambar 5, menjadi lebih merata dan sama mendekati pencahayaan pada bagian tengah.

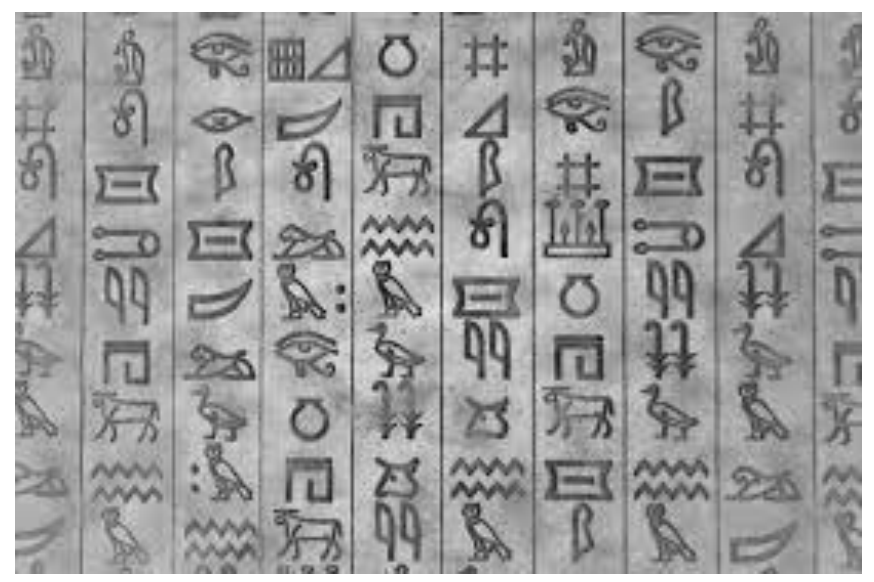

Gambar 7. Hasil Perataan Kecerahan

Distribusi intensitas yang merata pada setiap piksel, mempermudah proses thresholding untuk membuat gambar biner. Proses pencerahan menggunakan pola Gaussian tergantung pada nilai standar deviasi. Gaussian dengan dua variabel memerlukan simpangan baku untuk mengisi nilai dalam setiap sel dari matriks gaussian. Simpangan baku berpengaruh dalam menentukan nilai gaussian dalam setiap dua variabel $\mathrm{x}$ dan y sebagai alamat matriks gaussian sel.

Pada umumnya filter Gaussian digunakan untuk melakukan proses menghilangkan noise.[17] Salah satu persamaan pada Gaussian dapat dilakukan dengan Fungsi zero mean Gaussian dua variabel. Untuk mengisi elemenelemen pada matriks kernel Gaussian dapat dilakukan dengan menggunakan distribusi diskrit Gaussian. Seperti yang diperagakan pada rumus (3).[18][19][4]

$$
\mathrm{g}(\mathrm{x}, \mathrm{y})=\mathrm{c} \cdot e^{-\left(\mathrm{x}^{2}+\mathrm{y}^{2}\right) /\left(2 \cdot \sigma^{2}\right)}
$$

Nilai c yang dihasilkan dikalikan dengan masing-masing bobot nilai, sehingga menghasilkan matriks filter Gaussian, dengan $e$ Adalah konstanta euler dengan nilai 2.718281828. fungsi $\mathrm{g}(\mathrm{x}, \mathrm{y})$ adalah fungsi nilai Gaussian pada sel $(\mathrm{x}, \mathrm{y})$ sedangkan $\sigma^{2}$ adalah variant dari distribusi. Nilai Gaussian inilah yang akhirnya di susun menjadi matriks brightness untuk perataan kecerahan citra.[6]

\section{METODE}

Sel-sel pada matriks Gaussian brightness sudah memiliki alamat nya masing-masing yang direpresentasikan dengan kolom dan baris. Sedangkan pada masing-masing selnya terdapat nilai-nilai pencerah citra. Jadi pada sel-sel matriks Gaussian terdapat 3 nilai, yaitu nilai alamat kolom, nilai alamat baris dan nilai pengisi sel tersebut.

Setiap titik pada grafik 3D memiliki koordinat $\mathrm{X}$, Y dan Z. berdasarkan alamat koordinatnya, titik-titik tersebut akan diproyeksi sehingga dapat diproyeksikan pada bidang 2D sehingga dapat dilihat secara visual.

Berdasarkan fakta-fakta tersebut, disusun metode untuk memvisualisasikan matriks Gaussian brightness dalam bentuk grafik 3D. Grafik 3D ini akan disajikan dalam bentuk 
proyeksi paralel sehingga semua titik disajikan dalam jarak yang proposional satu dengan yang lainnya sesuai dengan posisi titik mewakili letak sel matriks nya.

\section{A. Penentuan Koordinat}

Proyeksi 3D parallel memerlukan koordinat 3D yang terdiri dari koordinat $\mathrm{x}, \mathrm{y}$ dan $\mathrm{z}$. Koordinat $\mathrm{X}$ dan $\mathrm{Y}$ diterapkan sebagai kolom dan baris dari matrik pola brightness Gaussian. Dengan $\mathrm{X}$ sebagai kolom dan $\mathrm{Y}$ sebagai baris. Sedangkan sebagai sumbu $\mathrm{Z}$ diterapkan diterapkan sebagai nilai isi sel matriks.

Kolom dan baris matriks pola Gaussian brightness dimulai dari sel 0,0, dengan demikian maka koordinat $\mathrm{x}$ dan y juga dimulai dari koordinat 0,0 sampai koordinat tinggi citra, lebar citra. Nilai z ditentukan berdasarkan nilai isi sel.

\section{B. Ukuran Kanvas Grafik dan Sumbu Koordinat}

Ukuran kanvas untuk menggambar grafik ditentukan lebar kanvas 3 kali lebar citra dan tinggi kanvas adalah 3 kali tinggi citra. Tujuan dari dari ukuran yang diperbesar 3 kali ini agar grafik yang akan digambar dengan sudut $\alpha$ atau sudut $\Phi$ manapun tetap berada di bidang gambar.

Titik pusat koordinat kartesius $(0,0)$ dari bidang gambar ditetapkan pada tengah-tengah kanvas pada koordinat (Px, $\mathrm{Py}$ ) atau pusat $\mathrm{X}$ dan pusat $\mathrm{Y}$ pada koordinat kanvas Sumbu koordinat $\mathrm{x}$ digambar mulai dari koordinat kanvas $(0, \mathrm{Py})$ sampai (lebar kanvas, Py). Sumbu koordinat y digambar mulai koordinat kanvas (Px, 0) sampai (Py, tinggi kanvas).

Sumbu koordinat $\mathrm{z}$ digambar dari $\mathrm{z}=1000$ sampai $\mathrm{z}=-$ 1000, penggunaan nilai 1000 ini dilakukan dengan tujuan agar hasil proyeksi titik-titik tersebut berada di luar kanvas. Meskipun pada sudut $\Phi$ tertentu garis koordinat yang digambar akan mengecil, tetapi setidaknya menghasilkan panduan garis koordinat $\mathrm{Z}$. Karena sumbu $\mathrm{Z}$ berada di koordinat kartesius $(0,0)$ maka $x$ ditentukan sebagai $x=0$ dan $y$ ditentukan sebagai $y=0$. Setelah $z=1000$ dan $z=-1000$ masing-masing dicari nilai proyeksinya, maka didapat masing-masing koordinat proyeksi Xp dan Yp dari $z=1000$ dan $\mathrm{Z}=-1000$ tersebut.

\section{Penerapan Kaidah Tangan Kanan}

Penerapan kaidah tangan mensyaratkan sumbu $\mathrm{x}$ yang bernilai positif mengarah ke kanan, sumbu y yang bernilai postif mengarah ke atas, sedangkan sumbu $\mathrm{z}$ yang mengarah ke pengguna adalah sumbu ke arah positif.

Ciri khusus dari matriks pola gaussian adalah pusat matriks merupakan nilai yang terbesar dan menyebar ke pinggir semakin mengecil. Hal ini mempermudah implementasi menggambarkan grafik 3D. Untuk menerapkan ini, maka sumbu $\mathrm{z}$ yang tertinggi digambar paling terakhir, dalam hal ini pusat gaussian merupakan titik tertinggi, sehingga pusat digambar paling terakhir.

Penggambaran koordinat $\mathrm{x}$ dan $\mathrm{y}$ dipermudah dengan menggambarkan mulai koordinat $(0,0)$ sampai koordinat(lebar-1, tinggi-1) yang diterapkan dengan perulangan/loop menggunakan FOR sebagai predicted loop.

Arah sumbu y dari koordinat 3D berbeda dengan indeks baris pada matriks, karena itu agar hasil sesuai dengan matriks, input $\mathrm{Y}$ pada saat akan melakukan proyeksi harus dibalik.

Karena arah sumbu $\mathrm{Y}$ dari koordinat merupakan kebalikan dari indek baris matriks pola brightness, maka loop indeks Y harus dibalik juga agar bagian bawah dari grafik digambar terlebih dahulu.

Nilai pada tiap sel matriks gaussian brightness dapat diterapkan sebagai nilai koordinat $\mathrm{Z}$, sehingga menghasilkan grafik 3D yang sesuai dengan matriks pola brightness.

Setiap sel pola brightness, sudah berisi nilai-nilai brightness yang merupakan nilai $\mathrm{z}$, karena itu untuk implementasi ini hanya melakukan loop baris dari $\mathrm{y}=0$ sampai $\mathrm{y}=$ height-1 dan di dalamnya terdapat loop kolom mulai dari $\mathrm{x}=0$ sampai $\mathrm{x}=$ width -1

Agar menimbulkan kesan berbeda pada bagian yang jauh dari mata dengan bagian yang dekat mata, maka warna piksel yang akan mengisi grafik ditentukan berdasarkan warna yang paling terang yang diterapkan pada piksel dengan sumbu $\mathrm{Z}$ yang paling dekat dengan pengamat dan semakin gelap apa piksel dengan sumbu $\mathrm{z}$ yang menjauhi pengamat.

Kondisi ini dipengaruhi oleh nilai sudut $\alpha$ dan sudut $\Phi$ yang diberikan. Kombinasi sudut $\alpha$ dan sudut $\Phi$ ini terdiri dari 4 kondisi, yaitu

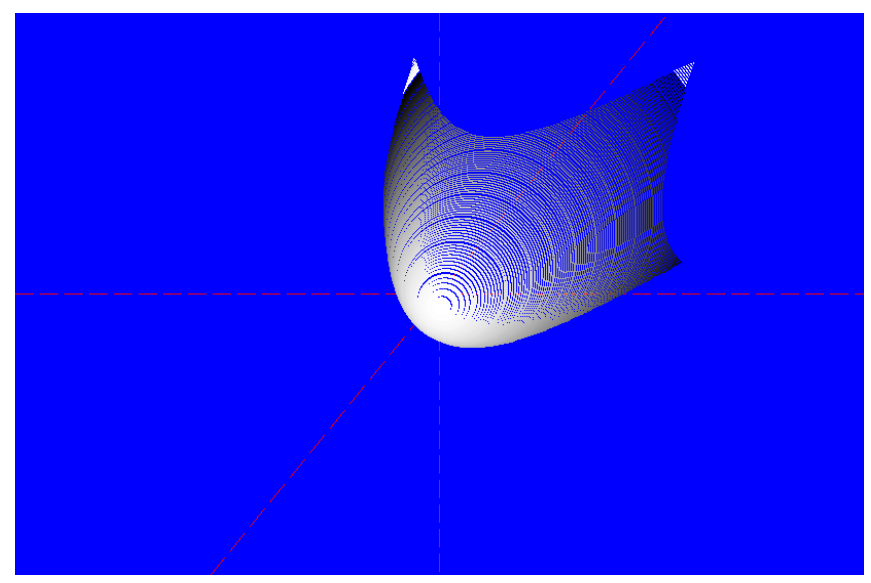

Gambar 8. Grafik Dengan $\alpha<90^{\circ}$ dan $\Phi>0^{\circ}$

Kondisi 1: $\quad$ sudut $\alpha$ bernilai kurang dari $90^{\circ}$ yang berarti posisi pengamat berada di depan sumbu Z, dan sudut $\Phi$ bernilai positif yang berarti Pengamat berada di sebelah kanan sumbu Z. ditunjukkan pada gambar 8 .

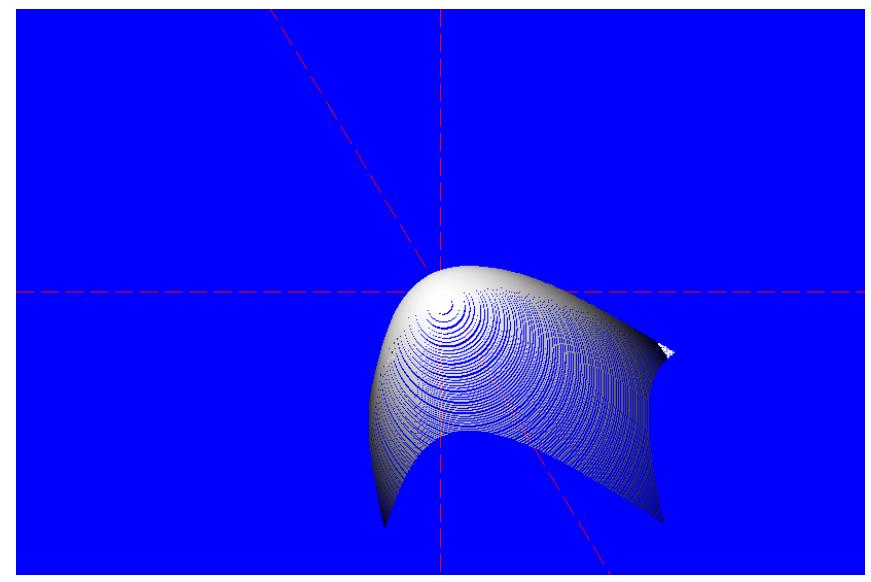

Gambar 9. Grafik Dengan $\alpha<90^{\circ}$ dan $\Phi<0^{\circ}$

Kondisi 2: Sudut $\alpha$ bernilai kurang dari $90^{\circ}$ yang berarti posisi pengamat berada di depan sumbu Z, dan sudut $\Phi$ 
bernilai negatif yang berarti Pengamat berada di sebelah kiri sumbu Z. ditunjukkan pada gambar 9.

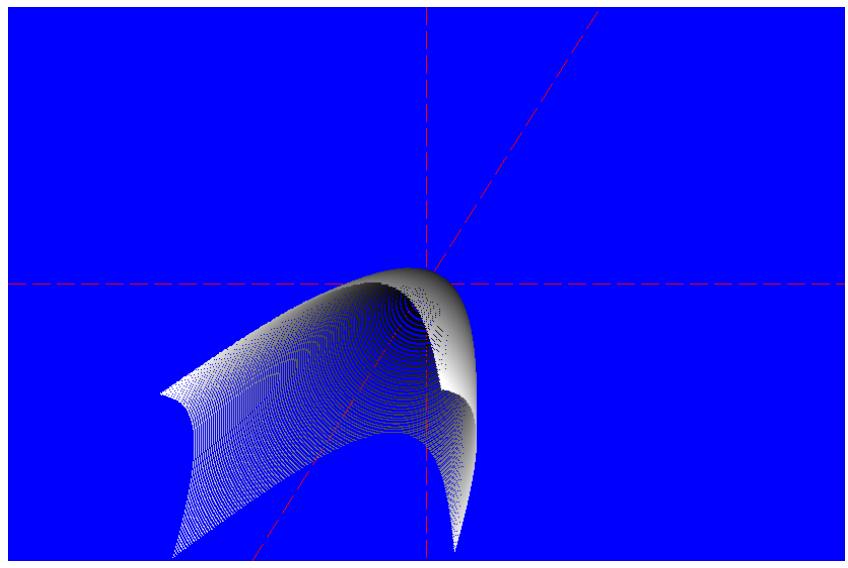

Gambar 10. Grafik Dengan $\alpha>90^{\circ}$ dan $\Phi>0^{\circ}$

Kondisi 3: Sudut $\alpha$ bernilai lebih dari $90^{\circ}$ yang berarti posisi pengamat berada di belakang sumbu Z, dan sudut $\Phi$ bernilai negative yang berarti Pengamat berada di sebelah kiri sumbu Z . ditunjukkan pada gambar 10.

Kondisi 4: Sudut $\alpha$ bernilai lebih dari $90^{\circ}$ yang berarti posisi pengamat berada di belakang sumbu Z, dan sudut $\Phi$ bernilai positif yang berarti pengamat berada di sebelah kanan sumbu Z . ditunjukkan pada gambar 11.

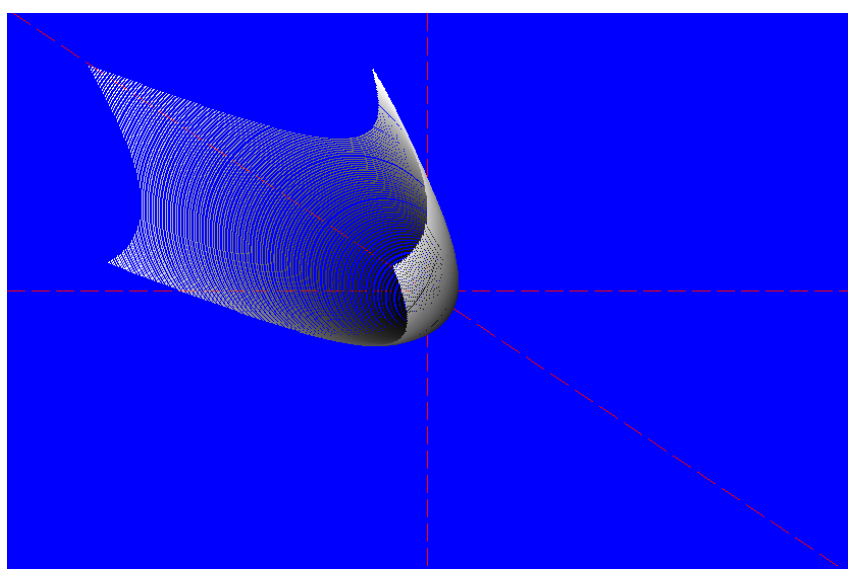

Gambar 11. Grafik Dengan Sudut $\alpha>90^{\circ}$ dan Sudut $\Phi<0^{\circ}$

Kondisi 1 dan kondisi 2 mengakibatkan seakan puncak dari matriks berada di dekat pengambat sedangkan kondisi 3 dan 4 mengakibatkan puncak dari matrik berada jauh dari Pengamat. Karena itu kondisi 1 dan kondisi 2 digambarkan dengan nilai $\mathrm{z}$ yang tinggi dibuat semakin cerah. Kondisi 3 dan kondisi 4 digambarkan dengan $\mathrm{z}$ yang tinggi dibuat semakin gelap.

Warna piksel berkisar antara 0 sampai 255, untuk menerapkan hal tersebut, maka warna piksel ditentukan dengan nilai sel di bagi nilai pusat matriks untuk menghasilkan perbandingan nilai dari sel tersebut. Hasil perbandingan sel dengan pusat matriks dikalikan dengan 255, sehingga menghasilkan nilai 0 sampai 255 saja yang digunakan untuk mengisi nilai piksel sesuai dengan kedekatan piksel dengan pengamat.
Pengaruh sudut $\Phi$ terhadap grafik diatur dengan orientasi penggambaran piksel. Jika $\Phi$ bernilai positif, maka piksel digambar mulai dari matrik pada sel[0, tinggi] sampai sel[lebar,0]. Sedangkan jika sudut $\Phi$ bernilai negatif, maka piksel digambar mulai dari sel[lebar,0] sampai [0,tinggi]. Hal ini dilakukan karena indek baris pada matriks yang mempergunakan array berkebalikan arah dengan sumbu Y pada koordinat kartesius.

Isi dari kedua proses tersebut sama, berupa penentuan warna piksel berdasarkan isi sel dari matriks brightness, yang dilanjutkan dengan penentuan nilai z berdasarkan selisih isi sel dengan pusat kecerahan matriks pola brightness. Pusat kecerahan matriks brightness ini bukan sel pusat matriks brightness, tetapi sel yang berisi nilai brightness yang terendah atau dengan kata lain bagian citra dengan pusat kecerahan tertinggi. Seperti yang sudah dijelaskan di atas, koordinat Y kartesius diinput terbalik dengan indek baris dari matriks gaussian brightness.

Langkah berikutnya adalah menentukan nilai proyeksi $\mathrm{Xp}$ dan Yp berdasarkan posisi koordinat $\mathrm{X}$ dan posisi koordinat Y. Grafik 3d kurva Gaussian ini diharapkan berada di tengah-tengah, karena itu posisi koordinat $\mathrm{X}$ pada grafik diatur sedemikian rupa sehingga sel[0,0] berada pada posisi koordinat (-lebar/2, -tinggi/2), dengan demikian sel pusat matriks berada pada koordinat $(0,0)$.

\section{HASIL DAN PEMBAHASAN}

Uji coba dilakukan untuk melihat keberhasilan implementasi proyeksi parallel dengan kaidah tangan kanan. Implementasi dianggap berhasil jika posisi puncak pada masing-masing kurtosis sesuai dengan gambar matriks yang tercantum di bawah gambar grafik 3D.

Sebagai perbadingan penelitian terdahulu adalah visualiasi dengan graphic 2D seperti yang diperagakan pada Gambar 6. Berdasarkan perbandingan kedua visualisasi tersebut, memiliki keuntungan masing-masing. Keuntungan visualisasi dengan graphic 2D tersebut adalah pengguna dapat melihat langsung kepekatan pola brightness yang dihasilkan oleh matriks Gaussian brightness. Sehingga user dapat meperkirakan seberapa besar kurtosis yang akan dibentuk. Kerugiannya adalah pengguna tidak memiliki visualisasi keberapa curam kurva 3D yang dibentuk oleh matriks Gaussian brightness.
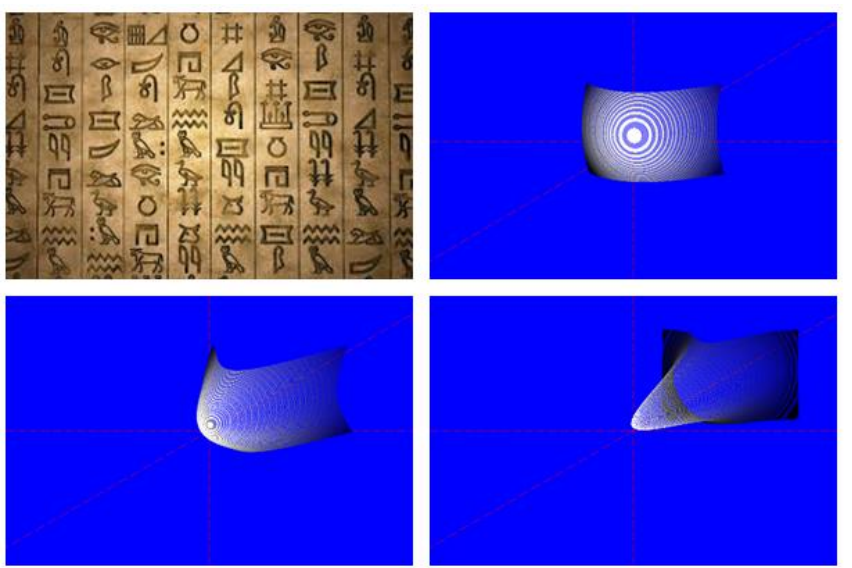

Gambar 12. Ujicoba Dengan Pengumpulan Cahaya Pada Tengah Citra 
Pada graphic 3D yang dibentuk yang dapat dilihat pada gambar 8, Gambar 9, Gambar 10, Gambar 11, Gambar 12 dan Gambar 13, kecuraman sel-sel matriks digambarkan secara visual. Penggunan graphic 3D ini memmungkinkan pengguna dapat memperoleh informasi visual seberapa besar kecuraman kurtosis yang dibentuk dari mariks Gaussian brightness yang dihasilkan.

Uji coba dilakukan dengan sudut $\alpha 45^{\circ}$ dan sudut $\Phi 30^{\circ}$, yang merupakan posisi sudut yang biasanya digunakan untuk menampilkan visualisasi grafik 3D parallel. Metode pengujian dilakukan terhadap tiga macam kurtosis: Leptokurtic, mesokurtic dan platikurtic.
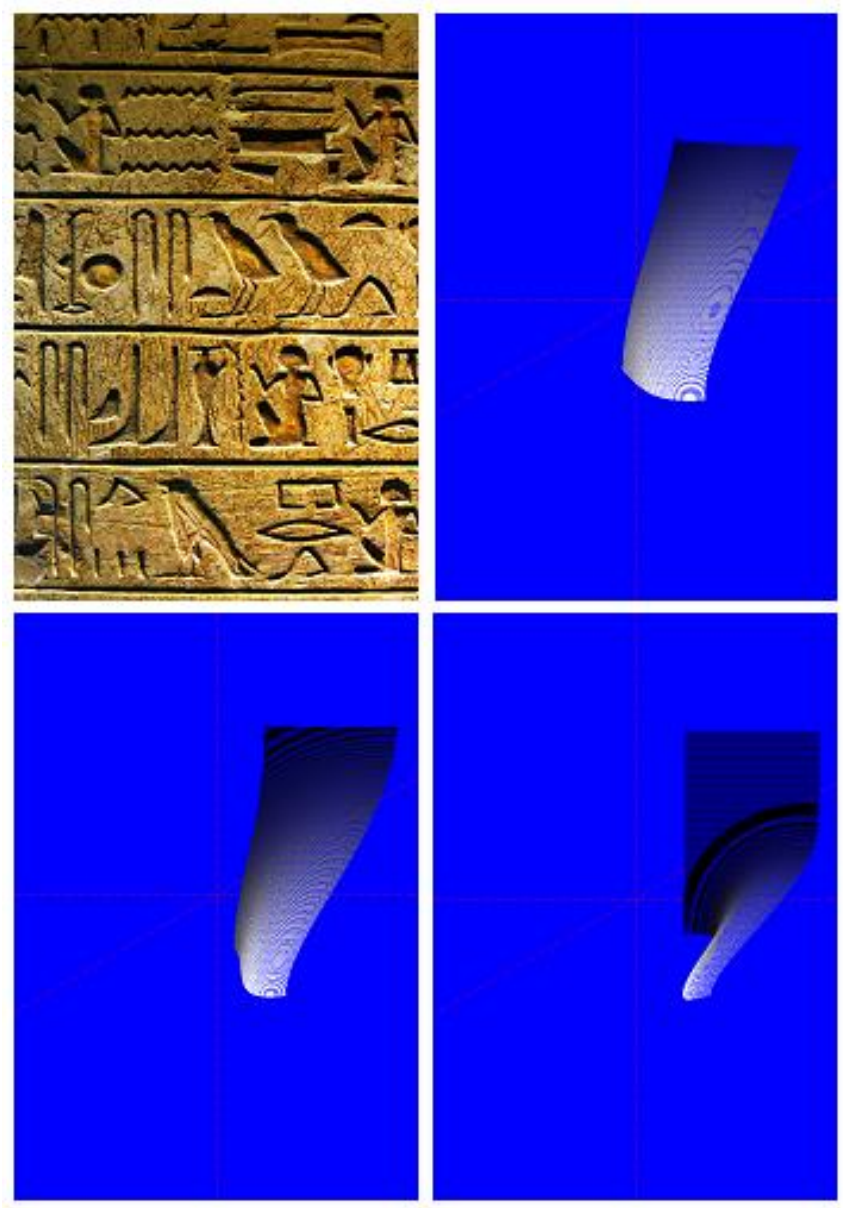

Gambar 13. Uji Coba Dengan Pengumpulan Cahaya Pada Sudut Citra

Uji coba juga dilakukan dengan kondisi yang ideal, dimana citra memiliki penumpukan cahaya tepat di tengahtengah citra. Kondisi yang ideal tersebut mengakibatkan kurva Gaussian dibentuk dengan puncak Gaussian ada di tengah-tengah kurva. Seperti yang diperagakan pada gambar 12. pada gambar tersebut secara berurutan dari kiri ke kanan, atas ke bawah adalah citra yang diuji, visualisasi grafik 3D Gaussian brightness dengan kurtosis platikurtik, visualisasi grafik 3D Gaussian brightness dengan kurtosis mesokurtik, dan visualisasi grafik 3D Gaussian brightness dengan kurtosis leptokurtik. Terlihat bahwa semua kurva menunjukkan puncak Gaussian brightness terdapat pada posisi yang dekat dengan pengamat.

Uji coba juga dilakukan dengan kondisi tidak ideal, seperti citra dengan penumpukan cahaya pada salah satu sudut saja, sehingga kurva Gaussian yang dibentuk tidak lengkap.

Pada semua pengujian yang dilakukan, semua pengujian menunjukkan kesesuaian posisi puncak grafik 3D dari lonceng Gaussian. Kesesuaian dengan bentuk kurtosis yang dihasilkan juga ditunjukkan oleh semua pengujian. Hal ini ditandai dengan voxel dengan warna yang cerah mewakili pusat penumpukan cahaya pada citra. Voxel dengan warna yang semakin gelap mengelili voxel dengan warna verah tersebut. Sampai ke voxel pada koordinat X dan Y yang semakin jauh dari pusat pengumpulan cahaya pada citra memiliki warna yang semakin gelap. Hal ini menandakan penentuan nilai $\mathrm{Z}$ untuk mewakili nilai pada sel matriks Gaussian brightness sudah sesuai, dalam hal ini kadar kedalaman dari kurva 3D matriks Gaussian brightness dapat terwakili oleh koordinat Z pada grafik 3D.

Kesesuaian penggunaan kaidah tangan kanan ditandai dengan posisi yang dianggap puncak berada seakan-akan dekat dengan pengamat dan voxel yang jauh dari pengamat tertutup oleh voxel yang lebih dekat dengan pengamat. pada pola Gaussian brightness dipengaruhi oleh nilai tiap sel matriks dengan sudut $\alpha$ dan posisi x dan y berdasarkan sudut $\Phi$. Karena sifat dasar dari kaidah tangan kanan ini, maka nilai matriks brightness yang diwakili oleh sumbu $\mathrm{Z}$ akan digambar terlebih dahulu, mengingat nilai ini terdapat pada sel-sel yang lebih tepi dari matriks Gaussian brightness. Dan karena sumbu Y mengarah ke atas, maka bagian atas dari matriks akan digambar terlebih dahulu.. sedangkan sel matriks akan pada kolom akan digambar terlebih dahulu. Sel-sel matriks yang voxelnya digambar terlebih akan tertutup oleh voxel yang digambar kemudian. Proses ini mengakibatkan tidak diperlukannya proses sorting pada voxel pengisi grafik 3D

\section{KESIMPULAN}

Secara keseluruhan sorting pada voxel pengisi grafik 3D dari pola Gaussian brightness teratasi berdasarkan nilai tiap sel matriks pada sudut $\alpha$ dan posisi $\mathrm{x}$ dan y berdasarkan sudut $\Phi$.

Pengaturan gradasi warna berdasarkan nilai matriks Gaussian brightness dapat menunjukkan posisi kurva Gaussian yang dekat dengan Pengamat System," Int. J. Comput. Appl. (0975 - 8887), vol. Volume 123, no. August 2015, hal. 28-31, 2017.

A. Dessie, F. Adane, A. Nega, S. D. Wami, dan D. H. Chercos, "Computer Vision Syndrome and Associated Factors among Computer Users in Debre Tabor Town , Northwest Ethiopia," J. Environ. Public Health, vol. 2018, no. Volume 2018, Article ID 4107590, hal. 1-8, 2018.

[3] T. Nadu, R. Co-ordinator, dan T. Nadu, "Introduction : - Related works : - Problem statement: -," Int. J. Adv. Res. (ISSN 23205407), vol. 4, no. 2, hal. 1006-1012, 2016.

[4] K. P. Mansfield, "Architectural lighting design: A research review over 50 years," Light. Res. Technol., vol. 50, no. 1, hal. 80-97, 2018.

[5] P. Parida dan N. Bhoi, "Engineering Science and Technology, an International Journal Transition region based single and multiple object segmentation of gray scale images," Eng. Sci. Technol. an Int. J., vol. 19, no. 3, hal. 1206-1215, 2016.

[6] T. M. S. Mulyana dan Herlina, "Evenly brightening using kurtosis Gaussian pattern to simplify image binarization," $J$. Phys. Conf. Ser., vol. 1397, hal. 012076, Des 2019.

[7] M. P. Lee, G. J. T. Cooper, T. Hinkley, G. M. Gibson, M. J. Padgett, dan L. Cronin, "Development of a 3D printer using 
scanning projection stereolithography," Sci. Rep., vol. 5, 2015. M. Omar, D. F. Ali, M. Mokhtar, N. M. Zaid, H. Jambari, dan N. H. Ibrahim, "Effects of Mobile Augmented Reality (MAR) towards students' visualization skills when learning orthographic projection," Int. J. Emerg. Technol. Learn., vol. 14, no. 20, hal. $106-119,2019$.

[9] P. Shirley, "Generating Stratified Random Lines in a Square," $J$. Comput. Graph. Tech. (ISSN 2331-7418), vol. 6, no. 2, hal. 4854, 2017.

[10] W. Feng, Y. A. N. Xue, W. Ming, Z. Xu, N. I. U. Xue, dan W. Qing, “一种生成新坐标系的普适三点模型及其应用,”吉林大 学学报 (工学版) J. Jilin Univ. Technol. Ed., vol. Vol. 50 No, no. Jan 2020, hal. 324-332, 2020.

[11] Y. Wang, J. Wang, M. Wen, W. Yi, dan L. Kong, "Track-beforedetect algorithm for airborne radar system,” J. Eng., vol. 2019, no. 20, hal. 6620-6624, 2019.

[12] A. Kissai dan M. Smith, "Electronic Navigation System based on the use of Alternate Coordinate System and Polar Stereographic Projection for UAVs operating in Polar Regions," Int. J. Aeronaut. Aerosp. Eng., vol. 1, no. 2, hal. 46-53, 2019.

[13] A. M. Glazer, "Confusion over the description of the quartz structure yet again," J. Appl. Crystallogr., vol. 51, hal. 915-918, 2018.
[14] T. Stojanovski, "Volatility and Kurtosis of Daily Stock Returns At Mse," UTMS J. Econ., vol. 6, no. 2, hal. 209-221, 2015.

[15] M. K. Cain, Z. Zhang, dan K.-H. Yuan, "Univariate and multivariate skewness and kurtosis for measuring nonnormality: Prevalence, influence and estimation," Behav. Res. Methods, vol. 49, no. 5, hal. 1716-1735, 2017.

[16] P. Amoako-Yirenkyi, J. K. Appati, dan I. K. Dontwi, "Performance Analysis of Image Smoothing Techniques on a New Fractional Convolution Mask for Image Edge Detection," Open J. Appl. Sci., vol. 06, no. 07, hal. 478-488, 2016.

[17] L. kabbai, A. Sghaier, A. Douik, dan M. Machhout, "FPGA implementation of filtered image using 2D Gaussian filter," Int. J. Adv. Comput. Sci. Appl., vol. 7, no. 7, hal. 514-520, 2016.

[18] I. Mezher, Liqaa S., Department of Electrival Engineering, AlMustansiriyah University, Baghdad, "Digital Image Processing Filtering with LABVIEW," Int. J. Comput. Sci. Trends Technol. (IJCS T), vol. 4, no. 4, hal. 278-282, 2016.

[19] D. Sur, S. Rudra, S. Mitra, dan S. Mitra, "A Case Study on Effects of Low Pass Filtering over Facial Image Processing and Proper Edge," Int. J. Innov. Res. Sci. Eng. Technol., vol. 5, no. 7, hal. 13394-13402, 2016. 